\title{
Pemetaan Kebutuhan Bahasa Inggris pada Masyarakat Daerah Potensi Wisata Kabupaten Bangka Provinsi Kepulauan Bangka Belitung
}

\author{
Dini Wulansari', M. Afifulloh ${ }^{2}$ \\ Universitas Bangka Belitung

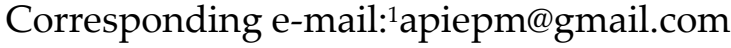

\begin{abstract}
Abstrak.Penelitian ini bertujuan untuk memetakan kapasitas dan kemampuan bahasa Inggris masyarakat dibeberapa lokasi wisata di kabupaten Bangka. Penelitian ini juga memetakan kebutuhan masyarakat akan bahasa Inggris sebagai keterampilan/kemampuan penunjang dalam upaya mengoptimalkan performa daerah serta jenis-jenis kemampuan bahasa Inggris yang dibutuhkan oleh masyarakat tersebut.

Penelitian ini merupakan penelitian deskriptif kualitatif. Data diperoleh dari hasil observasi, wawancara secara mendalam (depth interview) dan recording. Data diambil dalam kurun waktu 3 bulan yaitu bulan Juli - September 2017 dengan informan terdiri dari pemerintah daerah (dinas pariwisata), aparatur penyelenggara pemerintahan desa, kampung atau kelurahan dan masyarakat umum. Penelitian ini berlokasi di Pantai Matras sekitarnya dan Pantai Rebo sekitarnya.

Hasil penelitian ini menunjukkan bahwa masyarakat potensi wisata di Kabupaten Bangka yaitu daerah pantai Matras rata-rata memiliki kemapuan bahasa Inggris yang rendah sehingga mereka sangat membutuhkan pelatihan khususnya untuk kemampuan berbicara (speaking) dan mendengarkan (listening). Hal ini juga membuktikan bahwa tingkat kebutuhan masyarakat daerah pantai Matras akan bahasa Inggris dalam menunjang pengembangan potensi wisatanya sangat tinggi. Sementara, masyarakat yang tinggal di wilayah pantai Rebo terbagi menjadi dua kelompok yaitu kelompok yang membutuhkan bahasa Inggris (masyarakat yang tinggal di desa Rebo), dan yang tidak menunjukkan minat dan kebutuhan akan bahasa Inggris (masyarakat yang tinggal di pesisir pantai Rebo). Keengganan masyarakat untuk menguasai bahasa Inggris dipicu oleh tingkat pendidikan yang rendah dengan mata pencaharian mayoritas nelayan sehingga mereka tidak memiliki banyak waktu luang dan lebih mementingkan kebutuhan ekonomi saja, serta belum tertatanya potensi wisata yang ada. Hasil penelitian ini juga menunjukan adanya keinginan yang kuat dari masyarakat akan adanya pelatihan bahasa Inggris secera berkelanjutan meskipun seminggu sekali. Harapan mereka adalah pelatihan tersebut agar difasilitasi oleh pemerintah maupun Lembaga Swadaya Masyarakat (LSM) sehingga mereka bisa belajar dengan gratis.
\end{abstract}

Keyword:Pemetaan, Pariwisata, Kabupaten Bangka, Potensi Wisata Lokal, Bahasa Inggris

\section{Submited: 30 Januari $2018 \quad$ Accepted : 23 Maret $2018 \quad$ Published : 28 Maret 2018}

\section{PENDAHULUAN}

Sektor pariwisata merupakan salah satu sektor unggulan dalam proses pembangunan suatu daerah. Pariwisata didefinisikan sebagai kegiatan perjalanan yang dilakukan oleh seseorang atau sekelompok orang dari satu tempat ke tempat lain dengan berbagai tujuan seperti 
rekreasi, menambah pengetahuan, mencari ide baru, dan lain sebagainya. Pariwisata berpotensi menciptakan pertumbuhan yang progresif dan peluang yang berharga dengan didukung oleh kekayaan alam dan keberagaman lokalitas. Pemanfaatan pariwisata secara maksimal dapat menjadi ujung tombak untuk memperoleh pendapatan daerah yang tinggi. Kemampuan masyarakat dalam mencukupi kebutuhannya otomatis akan meningkat. Tidak hanya masyarakat yang berperan namun idealnya pemerintah daerah juga ikut berkontribusi dengan memberikan kesempatan terhadap pengembangan wisata lokal. Pemerintah adalah lembaga yang paling bertanggung jawab terhadap penyediaan infrastruktur pariwisata (Judisseno, 2017:197).

Perumusan kebijakan dan pencanangan suatu wilayah sebagai Destinasi Tujuan Wisata (DTW) mengindikasikan kepedulian, komitmen, dan peran pemerintah sebagai upaya memajukan pariwisata yang diatur dan tertuang dalam UU No. 10 tahun 2009 pengganti UU No. 9 tahun 1990 tentang kepariwisataan. Peraturan ini menyebutkan bahwa pengembangan kepariwisataan dapat memberikan dampak positif bagi masyarakat antara lain berupa peningkatan kesejahteraan masyarakat, pengurangan angka kemiskinan dan pengangguran, serta pelestarian lingkungan.

Salah satu wilayah di Provinsi Kepulauan Bangka Belitung yang juga melakukan kegiatan kepariwisataan adalah Kabupaten Bangka atau dikenal dengan sebutan Bangka Induk. Kabupaten Bangka menjadi pusat pemerintahan pulau Bangka sewaktu Kepulauan Bangka Belitung belum memisahkan diri dari Provinsi Sumatera Selatan. Kabupaten Bangka dipilih sebagai lokasi penelitian karena (1) Kabupaten ini memiliki banyak potensi wisata yang bernilai ekonomis terutama spot pantai antara lain: Pantai Matras di Desa Matras Kec. Sungailiat, Pantai Parai Tenggiri di Desa Matras Kec. Sungiliat, Pantai Batu Bedaun di Desa Kuala Kec. Sungailiat, Pantai Teluk Uber di Desa Rambak Kec. Sungiliat, Pantai Tanjung Pesona di Desa Rambak Kec. Sungiliat, Pantai Tikus di Desa Rebo Kec. Sungiliat, Pantai Air Anyir Kec Merawang, Pantai Penyusuk Kec. Belinyu, Pantai Romodong di Desa Bukit Ketok Kec. Belinyu, Pantai Kuala di Desa Kuala Kec. Sungailiat, Pantai Tj. Belayar Kec. Sungailiat, Pantai Rebo Kec. Sungailiat, Pantai Tj. Ratu Kec. Sungailiat, Pantai Bedukang Kec. Riau Silip, dan lain sebagainya, serta hutan wisata dan pemandian air panas; (2) masih belum optimalnya pengelolaan dan pengembangan potensi-potensi wisata tersebut oleh pemerintah daerah dan masyarakat baik dalam pengelolaan SDA, sarana prasarana yang tersedia, upaya pelestarian budaya lokal dan lingkungan, pemberdayaan masyarakat berbasis wisata, serta sosialisasi atau promosi secara menyeluruh.

Pengembangan pariwisata di Kabupaten Bangka terindikasi berada dalam posisi stagnan karena terkendala pada berbagai kepentingan. Menjamurnya spot-spot yang dikelola dengan apik oleh pihak swasta menambah daya saing yang cukup signifikan bagi keberlangsungan pariwisata ke depannya. Dalam konteks pariwisata, perencanaan yang menyeluruh tentu diperlukan untuk mengantisipasi dan menjawab berbagai tuntutan wisatawan/pengunjung.

Dengan kata lain, majunya suatu kawasan wisata harus ditopang dengan tingkat kualitas SDA, dan wawasan SDM pada kawasan setempat seperti wawasan terhadap kegiatan kepariwisataan, dan kemampuan/keterampilan berkomunikasi dengan wisatawan mancanegara atau domestik. Kemampuan dan keterampilan 
berkomunikasi tersebut merujuk kepada salah satu unsur pendukung kemajuan potensi wisata yaitu bahasa asing khususnya bahasa Inggris. Mengingat bahasa Inggris adalah sarana komunikasi yang digunakan oleh masyarakat internasional, penguasaan bahasa ini menjadi penting jika pemerintah daerah ingin menarik minat wisatawan tidak hanya domestik namun juga mancanegara sebagai penyumbang devisa dan pendapatan daerah. Melalui penguasaan bahasa Inggris, ketergantungan akan penerjemah dapat dibatasi karena masyarakat dapat berkomunikasi dengan sendirinya. Wisatawan asing juga tidak perlu ragu dan takut tersesat karena masyarakat setempat dapat diandalkan sebagai guide yang akan membantu wisatawan menikmati destinasi wisata.

Penelitian yang berjudul "Pemetaan Kebutuhan Bahasa Inggris pada Masyarakat Potensi Wisata (Studi di Kabupaten Bangka)" menekankan pada kebutuhan bahasa Inggris sebagai fokus kajian karena dikaitkan dengan sisi bidang ilmu peneliti yang mencoba melihat pariwisata dari kacamata bahasa yaitu bagaimana bahasa dapat membantu daerah dalam mengembangkan potensi wisatanya menuju internasional. Melalui penelitian ini, diharapkan dapat membantu pemerintah daerah dalam menyelenggarakan program masyarakat berbasis pariwisata misalnya pelatihan atau pendampingan bahasa Inggris di Kabupaten Bangka. Peneliti memetakan beberapa lokasi yang menjadi kawasan wisata berdasarkan rekomendasi Dinas Pariwisata yang diasumsikan memerlukan kemampuan bahasa Inggris sebagai alat penopang dalam meningkatkan taraf kehidupan masyarakat melalui penguatan pariwisata dan juga mengkaji peluang bahasa Inggris bagi masyarakat sekitar lokus sebagai bagian dari prospek pengembangan potensi wisata yaitu Pantai Matras sekitarnya dan Pantai Rebo sekitarnya.

\section{METODE PENELITIAN}

Penelitian ini merupakan penelitian deskriptif kualitatif yaitu menggambarkan kebutuhan bahasa Inggris pada masyarakat potensi wisata di Kabupaten Bangka dalam bentuk pemetaan. Penelitian ini dilakukan sesuai dengan fakta yang ada atau fenomena yang memang secara empiris hidup pada penutur-penuturnya, sehingga yang dihasilkan atau yang dicatat berupa perian bahasa yang biasa dikatakan sifatnya seperti potret: paparan seperti apa adanya dan didasarkan pada data-data yang lengkap secara tipikal (bukan berdasarkan jumlah) mengingat dalam penelitian kebahasaan tidak membutuhkan rumusrumus statistik.

Fokus penelitian diambil berdasarkan rekomendasi dari Dinas Pariwisata Kabupaten Bangka, terdiri atas dua kawasan potensial yaitu kawasan Pantai Matras sekitarnya dan Pantai Rebo sekitarnya. Penelitian ini dilakukan mulai dari bulan Juli-September 2017. Subjek dalam penelitian ini adalah daerah potensi wisata di Kabupaten Bangka Provinsi Kepulauan Bangka Belitung. Objek kajiannya adalah masyarakat daerah potensi wisata yang membutuhkan bahasa Inggris dalam program pengembangan pariwisata.

Dalam mengumpulkan data berupa informasi yang lengkap dan akurat, kegiatan terjun langsung ke lapangan yang melibatkan mahasiswa sebagai bagian dari penelitian dilakukan dengan menggunakan beberapa metode shahih yaitu melakukan observasi dan melakukan wawancara secara mendalam (depth interview). Teknik pengamatan dilakukan dengan observasi subjek yang dikaji di 
dua lokasi yaitu Pantai Matras sekitarnya dan Pantai Rebo sekitarnya. Wawancara dilakukan untuk mendapatkan data yang valid mengenai kebutuhan bahasa Inggis pada masyarakat potensi wisata di Kabupaten Bangka. Wawancara dilakukan dengan beberapa pihak yang terlibat seperti pihak pemerintah daerah atau aparatur penyelenggara pemerintahan desa, kampung atau kelurahan, dan masyarakat sebagai pelaku pariwisata. Informan dipilih dengan cara purposive sampling, kemudian dilanjutkan dengan wawancara mendalam (depth interview). Wawancara dilakukan kepada masyarakat dan pemangku kepentingan yang terlibat dan bertanggung jawab dalam pengelolaan pariwisata secara keseluruhan. Semua data yang dihasilkan dicatat dan disusun sesuai dengan keaslian data tanpa dirubah-rubah. Tujuannya adalah untuk memberi interpretasi data yang akurat dan mendalam terhadap hal-hal yang muncul dalam fenomena yang diteliti.

\section{HASIL DAN PEMBAHASAN}

\section{Hasil Penelitian}

\section{Pantai Matras}

Pantai ini merupakan destinasi wisata yang telah dikembangkan oleh pemerintah Kabupaten Bangka, terletak di kecamatan Sungailiat tepatnya di desa Matras. Pantai ini bersebelahan dengan pantai Parai yang dikembangkan oleh pihak swasta. Penduduk desa Matras berjumlah 3.912 jiwa, dengan mayoritas berprofesi sebagai nelayan dan buruh/karyawan swasta. Petani berjumlah sekitar $10-15 \%$ dari total jumlah penduduk. Di daerah ini, angka putus sekolah masih cukup tinggi. Hal ini dikarenakan kurangnya kesadaran akan pentingnya pendidikan baik dikalangan orang tua maupun anak-anaknya. Orang tua lebih bangga jika anak-anaknya bisa menghasilkan uang sejak dini. Pada saat wawancara dengan kepala lingkungan desa Matras, dinyatakan bahwa karakteristik penduduk desa Matras sedikit berbeda dengan penduduk lain yang bukan daerah pesisir.

Penduduk Matras memiliki watak keras dan susah diatur. Mereka lebih mementingkan memenuhi kebutuhan ekonominya daripada kebutuhan lain seperti Pendidikan. Hanya sekitar 25\% saja yang menyelesaikan pendidikan hingga tingkat SMA dan bisa dihitung dengan jari penduduk yang melanjutkan ke tingkat lebih tinggi atau kuliah. Banyak remaja putus sekolah yang menjadi buruh atau pengangguran dan memicu tingkat kenakalan remaja seperti minumminuman keras dan lainnya.

Terlepas dari masalah sosial tersebut, desa Matras memiliki potensi wisata yang luar biasa. Pantai Matras dengan segala keeksotisannya menjadi daya tarik yang sulit untuk tidak disukai pengunjungnya. Dalam perkembangannya, saat ini Matras telah menjadi destinasi wisatawan lokal, nasional, maupun internasional. Mereka menghabiskan waktu di pantai Matras untuk berlibur dengan keluarga, mandi, bahkan wisatawan asing suka melakukan sky diving atau snorkeling di pantai ini hingga menghabiskan waktu seharian melakukan aktivitasnya di pantai ini.

\section{Pantai Rebo}

Pantai Rebo Bangka yang terletak di kampung Rebo, Desa Kenanga, kecamatan Sungailiat, Kabupaten Bangka. Garis pantai yang membentang sepanjang puluhan kilometer dengan tekstur tanah yang berbukit-bukit membuat pantai ini menjadi lokasi yang tepat untuk menikmati sunrise. Bentangan bebatuan granit yang berdiri dalam berbagai posisi membuat kunjungan wisatawan menjadi lebih menyenangkan karena bebatuan tersebut seakan menyediakan meja bahkan tempat tidur, tidak perlu kuatir barang- 
barang bawaan tercemar oleh pasir. Lokasi tersebut juga cocok untuk berkemah di antara bebatuan tersebut. Dari kejauhan tampak puluhan tambang apung mengambang di atas permukaan laut, dan begitu hari mulai beranjak siang, beberapa di antaranya mulai beroperasi dan mengeluarkan suara-suara mesin penyedot pasir yang masih banyak mengandung timah. Pantai Rebo berjarak hanya sekitar $8 \mathrm{~km}$ dari Kota Sungailiat.

Pantai ini sebenarnya merupakan daerah wisata bahari yang masih menjadi target pengembangan Pemda Kabupaten Bangka. Namun karena kurangnya perhatian dan ketegasan wisata bahari di Pantai Rebo, tambang inkonvensional (TI) apung dan TI darat mengambil alih area tersebut sebagai sumber mata pencaharian. Selain itu, kapal hisap juga dapat ditemukan di kawasan ini. Bekas galian, lubang-lubang, dan sedimentasi pasir tak beraturan membuat Pantai Rebo tak secantik dulu. Dulu (tahun 1990-an) di kawasan pantai ini dibangun dermaga sebagai tempat menambatkan perahu nelayan dan dibangun pondok-pondok sebagai tempat bersantai dan berteduh sambil menikmati keindahan pantai. Berlatar Bukit Rebo yang hijau, berpasir putih dan air lautnya yang biru jernih, Pantai Rebo menjadi salah satu aset wisata bahari penting di Kabupaten Bangka saat itu.

\section{Pembahasan}

\section{A. Pemetaan Kebutuhan Bahasa Inggris di Daerah Potensi Wisata}

Dalam penelitian ini, data kuesioner dan wawancara secara mendalam (depth interview) merupakan bahan kajian utama dalam menentukan pemetaan kebutuhan bahasa Inggris. Kuesioner yang disebar berupa daftar pertanyaan mengenai pengetahuan mereka tentang bahasa Inggris dan seberapa perlunya bahasa Inggris dalam kebutuhan mereka sehari- hari sebagai masyarakat yang tinggal di daerah potensi wisata dan wawancara bersama pihak-pihak yang berkepentingan serta masyarakat umum.

Sebelum terjun ke lokasi, data dikumpulkan terlebih dahulu mengenai daerah-daerah potensi wisata yang ada di Kabupaten Bangka. Dalam hal ini, wewenang Dinas Pariwisata Kabupaten Bangka menjelaskan dan memberikan gambaran mengenai pariwisata dan potensi wisata di Kabupaten Bangka. Berdasarkan data tersebut, Kabupaten Bangka ternyata memiliki dua lokus potensi wisata yang menjadi perhatian pemerintah, yaitu di Kecamatan Sungailiat dan di Kecamatan Belinyu. Namun, Kecamatan Sungailiat adalah daerah yang merupakan lokus utama pemerintah dalam mengembangkan sektor pariwisata di Kabupaten Bangka. Banyak potensi wisata yang sudah dan sedang dikembangkan oleh pemerintah. Suherman (Kepala bagian pengembangan wisata Dinas Pariwisata Kabupaten Bangka) menyatakan bahwa Sungailiat saat ini sedang menjadi pembicaraan wisatawan karena keindahan tempattempat wisatanya terutama pantainya. Saat ini, ada beberapa destinasi wisata yang sudah dikembangkan oleh pemerintah maupun swasta seperti pantai Parai, Tongachi, pantai Tikus, pantai Tamberan, Temple of Heaven (Puri Tri Agung), dan lain-lainnya.

Untuk fasilatas seperti jalan raya menuju lokasi wisata, pemerintah terus membangun jalan demi memidahkan wisatawan menuju lokasi wisata. Namun dari segi penguatan Sumber Daya Manusia yang tinggal dilokasi potensi wisata, pemerintah masih belum maksimal. Hal ini dikarenakan beberapa faktor seperti rendahnya pendidikan yang dimiliki masyarakat tersebut, kesadaran masyarakat dalam berpartisipasi seperti 
ikut pelatihan masih rendah. Namun diakui juga bahwa pemerintah nampaknya masih kurang aktif dalam upaya meningkatkan sumber daya manusianya.

Seperti yang telah diketahui, bahasa Inggris merupakan sesuatu yang sebenarnya krusial dalam mengembangkan sektor pariwisata. Hal ini karena bahasa Inggris sebagai bahasa internasional, digunakan oleh wisatawan asing yang tidak bisa bahasa Indonesia dalam berkomunikasi. Komunikasi secara langsung antara wisatawan asing dan penduduk lokal tanpa bantuan penerjemah dapat membantu meningkatkan potensi destinasi wisata dan menjadi nilai lebih. Namun dalam kenyataannya, bahasa Inggris masih menjadi suatu hambatan bagi masyarakat. Tingkat pendidikan yang rendah, keengganan belajar dari masyarakat serta ketiadaan pelatihan peningkatan kualitas SDM dari stakeholder atau pemerintah menjadi faktor yang jamak ditemukan dilokasi penelitian. Berikut ini merupakan gambaran pemetaan kebutuhan bahasa Inggris dari hasil survei dan kuesioner yang berhasil dikumpulkan.

\section{Pantai Matras}

Pantai matras merupakan pantai yang sering dikunjungi oleh wisatawan asing. Hal tersebut dikuatkan oleh salah satu penjaga pantai saat wawancara. Dalam wawancara tersebut disebutkan bahwa wisatawan asing berkunjung ke pantai Matras merupakan tamu atau pengunjung yang ingin melakukan diving atau sekedar ingin menikmati makan di dekat pantai dengan membakar ikan di tepi pantai. Dalam wawancara tersebut juga dijelaskan kesulitan-kesulitan dalam menghadapi wisatawan asing terutama saat berkomunikasi. Penjaga pantai di pantai ini umumnya belum memiliki kemampuan bahasa Inggris yang memadai sehingga mereka tidak bisa berkomunikasi langsung, lebih banyak mengandalkan jasa penerjemah dari biro travel setempat."Jika ada turis asing kami biasanya mengantar dan menunjukan lokasilokasi strategis untuk diving. Kami biasanya berkomunikasi dengan guidenya karena tidak mengerti bahasa Inggris"

(DT $01 \mathrm{M})$

Berbeda dengan penjaga pantai, pedagang yang tinggal di pantai Matras mengungkapkan bahwa jika ada turis asing yang berbahasa Inggris, biasanya kalua tidak memakai guide, cara berkomunikasi langsung dengan mereka adalah dengan mengandalkan bantuan smartphone. Pedagang biasanya mencari kata-kata dalam bahasa Inggris lewat smartphone dan kemudian mencoba menyusun kalimat sederhana agar turis tersebut mengerti. Hal ini diungkapkan oleh salah satu pedagang yang memang menetap di pantai Matras."Biasanya kami memakai bantuan HP buat membuat kalimat bahasa Inggris jika mereka mau berbelanja. Kemari nada orang India mau bakar ikan tetapi karena kesulitan bahasa Inggrisnya mereka tidak jadi beli. Mereka tidak bawa guide dan kami juga susah berbicara bahasa Inggris. Suami saya biasa yang bisa, tetapi sedikitsedikit dan pakai bantuan HP". (DT $02 \mathrm{M}$ )

Untuk mengetahui seberapa perlu kebutuhan pegiat wisata di pantai Matras terhadap bahasa Inggris, penulis memberikan kuesioner kepada masyarakat yang ada di sekitar matras. Kuesioner yang disebarkan sebanyak 30 lembar. Dari 30 lembar kuesioner, 23 dikembalikan dengan jawaban. Sisanya tidak dikembalikan dan tanpa keterangan. Dari pertanyaan-pertanyaan kuesioner tersebut dapat disimpulkan bahwa sebanyak 9 orang yang mengisi kuesioner tersebut berprofesi sebagai pedagang, 2 orang penjaga pantai, 4 orang bekerja di Badan SAR dan Penanggulangan Bencana Alam, 4 orang remaja putus sekolah, dan 4 orang adalah petani dan ibu rumah tangga.

Dari 23 kuesioner yang berisi jawaban penduduk tersebut, poin isian yang 
menanyakan kebutuhan bahasa Inggris di tempat tersebut, ada 2 kuesioner yang dijawab dengan tidak tahu, selebihnya menjawab perlu bahasa Inggris. 2 kuesioner dengan jawaban tidak tahu diisi oleh orang yang memiliki profesi ibu rumah tangga dan remaja putus sekolah. Kuesioner yang jawabannya membutuhkan bahasa Inggris, rata-rata menuliskan alasan yang hampir sama yaitu agar bisa berbicara bahasa Inggris dengan baik sehingga jika ada turis asing tidak perlu guide ataupun penerjemah. Adapun kebutuhan mereka akan berbahasa Inggris umumnya ada pada core skill speaking dan listening. Hal ini wajar mengingat mereka hanya membutuhkan untuk berkomunikasi dengan turis asing. Sementara ada satu jawaban yang beralasan bahwa bahasa Inggris itu perlu karena jika ada kegiatan seperti triathlon, pengelola pantai tidak perlu mencari bantuan ke guide atau penerjemah.

\section{Pantai Rebo}

Pantai Rebo merupakan pantai yang cukup menarik. Namun perhatian dan tata kelola yang kurang maksimal menjadikan pantai ini seperti tidak terurus. Penelitian dibagi menjadi dua lokasi yaitu daerah pesisir dan desa Rebo. Lokus difokuskan terpisah karena setelah diobservasi dan dilakukan kegiatan pengumpulan data, terdapat dua fenomena yang berbeda perlakuan.

a. Lokasi daerah pesisir pantai

Pantai ini diiisi dengan aktivitas nelayan dan dipenuhi anjing liar yang lalu lalang mencari makan. Hal ini membuat pengunjung segan mengunjungi pantai tersebut. Dengan sebagian masyrakat yang berprofesi sebagai nelayan, penduduk di sini terlalu sibuk untuk urusan akademis. Ketika diajak bicara untuk sekedar wawancara saja mereka menolak dengan alasan tidak tahu dan lebih suka menyuruh ke tempat orang lain di sekitar.

Karakteristik masyarakat tersebut menjadi kendala dan tantangan tersendiri dalam mengumpulkan data penelitian. Menurut keterangan dua orang informan yang merupakan pelajar SMA, pantai rebo memang dipenuhi oleh aktivitas nelayan dan itu terjadi setiap hari. Banyak kapalkapal nelayan yang bersandar untuk menurunkan tangkapan ikannya dan banyak orang lalu lalang sedang bertransaksi. Masih menurut remaja tersebut, masyarakat di sini memang tidak punya waktu untuk mengurusi hal-hal yang tidak ada hubungannya dengan jualbeli ikan terutama yang tinggal disekitar pantai. Dari fakta ini, dapat disimpulkan bahwa masyarakat di sekitar pantai rebo (pesisir) tidak terlalu membutuhkan bahasa Inggris sebagai salah satu unsur pendukung dalam mengembangkan sektor pariwisata.

Oleh karena itu, untuk penyebaran kuesioner disarankan agar tidak di daerah pantai melainkan di desa Rebo karena penduduknya tidak semua berprofesi sebagai nelayan dan kemungkinan mengerti masalah kuesioner. Selain mereka tidak peduli, mereka sebenarnya merupakan masyarakat yang kurang tinggi dari tingkat pendidikan dan banyak yang putus sekolah.

b. Lokasi di Desa Rebo

Realita di desa Rebo berbanding terbalik dengan di daerah pesisir pantai. Di desa Rebo latar belakang masyarakat lebih beragam sehingga menunjukkan tingkat pemikiran pun beragam. Dari 30 kuesioner yang disebar hanya satu berkas yang tidak diisi. Hal ini menandakan bahwa masyarakat desa Rebo antusias merespon penelitian ini. Mereka berharap akan ada tindak lanjut dari hasil penelitian walaupun jumlah wisatawan asing masih sangat terbatas yang datang. Informan 
berasal dari pelajar, karyawan, perangkat desa, IRT, buruh harian, dan pegawai pemerintah. Karena mereka tidak mengerti apalagi mahir berbahasa Inggris dan tidak ada penerjemah yang tersedia, mereka biasanya bersikap acuh tak acuh ketika wisatawan asing datang. Mereka pada dasarnya ingin berinteraksi namun masih terkendala dengan penguasaan bahasa asingnya. Salah satu poin penting yang dapat menjadi bahan pertimbangan bersama adalah peran pemerintah daerah dalam hal ini Dinas Pariwisata Kabupaten Bangka beserta pihak-pihak terkait untuk dapat lebih mengoptimalkan pengembangan wisata yang ada dan melibatkan masyarakat sebagai aset bergerak daerah.

Dari semua kuesioner yang dibagikan, semua sepakat menjawab bahwa bahasa Inggris perlu dilatihkan kepada mereka karena penting dalam menunjang profesi mereka yang erat kaitannya dengan wisata pantai. Dalam poin pernyataan kesedian belajar bahasa Inggris jika dilatihkan, 26 informan menjawab bersedia belajar, sementara 3 orang menjawab tergantung keadaan. Mereka yang menjawab tergantung keadaan karena waktu. Jika waktunya memungkinkan mereka bersedia ikut berlatih dan belajar bahasa Inggris. Oleh karena itu, dapat disimpulkan bahwa masyarakat desa Rebo sangat membutuhkan bahasa Inggris dalam menunjang pariwisata.

\section{B. Kapasitas Kemampuan Bahasa Inggris Masyarakat Potensi Wisata}

Ada beberapa hal yang ditemukan dilapangan yang berkaitan dengan faktorfaktor pendukung masyarakat belajar bahasa Inggris, yaitu:

i. Minat masyarakat yang tinggi Hal ini dapat dilihat dari hasil jawaban pertanyaan wawancara yang didapat selama penelitian. Dari total 53 informan, 45 informan menyatakan bersedia untuk mengikuti pelatihan/program pendampingan jika diadakan pelatihan bahasa Inggris secara gratis. Sisanya menjawab dengan jawaban tidak tahu dan tergantung keadaan jika memungkinkan.

ii. Adanya kesadaran akan pentingnya kemampuan bahasa Inggris dikalangan masyarakat sebagai aset pengembang pariwisata sehingga memberikan peluang bagi pemerintah atau pihak lain untuk melakukan tindak lanjut.

iii. Bahasa Inggris dianggap sesuatu yang dapat mendukung perkembangan potensi wisata sehingga kesediaan masyarakat berpartisipasi dalam pelatihan bahasa Inggris ada.

Dalam hal ini, penelitian di lapangan menunjukan bahwa meskipun beberapa faktor pendukung tersebut di atas ditemukan, namun mereka belum pernah mendapatkan pelatihan baik dari pemerintah maupun inisiatif sendiri dengan mengikuti kursus. Hal ini berdampak pada kemampuan bahasa Inggris mereka yang sangat rendah. Di pantai Matras misalnya, pedagang dan penjaga pantai yang beraktivitas dipantai tersebut mengalami kesulitan jika ada wisatawan asing yang datang. Mereka mengalami kesusahan dalam berbicara saat melakukan transaksi sehingga ada rasa ketidaknyamanan wisatawan asing tersebut untuk melakukan kontak sosial seperti membeli makanan atau minuman. Hal ini disampaikan oleh salah satu pedagang seperti kutipan hasil wawancara di bawah ini.

"Sebulan yang lalu ada rombongan orang india yang datang ke sini. Mereka merupakan wisatawan asing yang menginap di hotel Parai, datang ke sini untuk melihat 
pemandangan dan ingin bakar ikan dan jagung. Namun kami tidak paham dengan bahasa Inggris mereka sehingga wisatawan tersebut batal membeli dagangan kami." (DT 03 MT).

Dari hasil wawancara tersebut menunjukan bahwa kemampuan mereka dalam berbahasa Inggris masih rendah. Bahkan hanya untuk sekedar bertransaksi jual-beli saja mereka mengalami kesulitan. Hal ini berimbas pada berkurangnya minat wisatawan asing untuk bertransaksi dan juga merugikan pedagang tersebut karena dagangannya tidak jadi dibeli.

Dalam kesempatan lain, di pantai Rebo, juga ditemukan fenomena yang sama dengan pantai Matras. Kapasitas mereka dalam berbahasa Inggris masih sangat rendah. Mereka sama sekali tidak tahu bahasa Inggris. Mungkin dikarenakan tingkat Pendidikan yang rendah dan aktivitas yang mereka lakukan hanyalah mencari ikan di laut.

Oleh karena itu, pelatihan bahasa Inggris pada dasarnya perlu dilakukan bagi masyarakat terutama masyarakat penggerak wisata alam. Masyarakat yang memang aktivitasnya berhubungan langsung dengan wisata alam sangat membutuhkan pelatihan bahasa Inggris guna memenuhi kebutuhannya dan ikut berpartisipasi mengembangkan dan membangun potensi wisata alam di daerahnya.

Dalam penelitian ini, peneliti juga menemukan beberapa kendala jika diadakan pelatihan bahasa Inggris. Secara umum, faktor yang menghalangi atau kendala masyarakat potensi wisata di Kabupaten Bangka adalah belum maksimalnya peran pemerintah atau stakeholder di tingkat masyarakat dalam penguatan sumber daya manusia pada wilayah potensi wisata. Masyarakat terkesan dibiarkan begitu saja dalam mengelola potensi wisata. Pantai Rebo menjadi satu-satunya tempat yang saat ini belum menunjukkan kesadaran penuh akan pentingnya bahasa Inggris dalam pengembangan potensi wisata. Kuantitas masih terkotak berdasarkan wilayah. Hal ini disebabkan karena:

1. Kesadaran masyarakat yang rendah terutama masyarakat pesisir pantai Rebo;

2. Tingkat Pendidikan yang rendah, mayoritas nelayan dan penambang dengan rutinitas pekerjaan dan waktu yang tidak menentu;

3. Belum tertatanya potensi wisata yang ada;

4. Lebih mementingkan kebutuhan ekonominya daripada hal-hal lain;

Karakteristik sebagian masyarakat pesisir yang cenderung keras dan sulit diatur dapat menjadi salah satu kendala dalam pengembangan bahasa Inggris untuk kemajuan pariwisata lokal.

\section{Ekspektasi Masyarakat dalam Belajar Bahasa Inggris}

Secara umum, masyarakat di pantai Matras berharap banyak kepada pemerintah daerah untuk melakukan sosialisai atau pelatihan pengembangan kemampuan bahasa Inggris. Mereka sepakat bahwa dengan memiliki kemampuan bahasa Inggris yang memadai akan membantu usaha mereka dalam memenuhi kebutuhan hidupnya dan membantu mengembangkan potensi wisata alam yang ada di daerahnya. Mereka secara umum sepakat diadakan pelatihan bahasa Inggris walaupun seminggu sekali. Rata-rata mereka menginginkan pelatihan kemampuan berbicara dan kemampuan mendengarkan dalam bahasa Inggris. Hal tersebut dapat dilihat dari hasil wawancara yang ada. Dari 53 informan yang berhasil diwaancarai semua menjawab bahwa 
berbicara (speaking) dan mendengarkan (listening) adalah dua core skills yang mereka butuhkan. Mereka merasa bahwa struktur atau grammar merupakan sesuatu yang penting namun hal itu bisa dipelajari secara perlahan dan akan paham dengan sendirinya jika kemapuan berbicara mereka meningkat. Semakin lancer berbicara, semakin mereka sadar akan kesalahan dan kekurangan struktur kalimatnya.

\section{PENUTUP \\ Kesimpulan}

Dalam penelitian ini ada dua lokus potensi wisata di kabupaten Bangka yang menjadi rekomendasi Dinas Pariwisata untuk dijadikan lokasi penelitian yaitu Desa Matras dan Desa Rebo.

Dari data yang dihasilkan dilapangan, penelitian ini dapat disimpulkan sebagai berikut:

a. Potensi wisata yang dimiliki oleh kabupaten Bangka sangat besar namun sebagian belum dimanfaatkan secara maksimal baik dari segi tatakelola maupun yang lainnya.

b. Pantai Matras dan pantai Rebo adalah dua potensi wisata pantai yang dimiliki Kabupaten Bangka dan belum dimaksimalkan fungsinya sebagai destinasi wisata utama.

c. Di pantai Matras dan pantai Rebo Infrastruktur dan sarana-prasarana masih kurang.

d. Secara umum, kemampuan bahasa Inggris masyarakat pantai Matras dan pantai Rebo masih rendah sehingga mereka belum mampu memnggunakannya dalam berkomunikasi.

e. Dalam penelitian ini, masyarakat pantai Matras ternyata memiliki kemampuan bahasa Inggris lebih memadai daripada masyarakat pantai Rebo. Hal ini dikarenakan beberapa faktor seperti kreatifitas masyarakat
Matras dalam menggunakan media smartphone sebagai sumber belajar mereka. Sementara di desa Rebo khususnya yang tinggal di area pantai tidak peduli dengan kegiatan-kegiatan yang berhubungan dengan pendidikan karena rata-rata adalah nelayan dan pedagang dengan latar belakang Pendidikan rendah.

f. Rendahnya kemampuan bahasa Inggris masyarakat tersebut mengakibatkan terhambatnya proses komunikasi atau kontak sosial masyarakat terhadap wisatawan asing yang datang. Mereka kesulitan ketika menwarkan barang dagangan dan jasa mereka sehingga wisatawan asingpun enggan melakukan penawaran.

g. Dari hasil penelitian didapatkan bahwa harapan atau ekpektasi mereka yang menginginkan adanya pelatihan bahasa Inggris secera berkelanjutan meskipun seminggu sekali. Harapan mereka adalah pelatihan tersebut agar difasilitasi oleh pemerintah maupun Lembaga Swadaya Masyarakat (LSM) sehingga mereka bisa belajar dengan gratis.

\section{Saran}

Penelitian ini penting jika digali lebih mendalam untuk pengembangan pariwisata Kabupaten Bangka ke depannya. Oleh karena itu, penelitian ini diharapkan dapat diteruskan dan dikaji melalui penelitian-penelitian lainnya. Selain itu, pemerintah daerah diharapkan dapat membuat terobosan baru bagi pariwisata daerah sehingga hasilnya akan lebih maksimal. 


\section{DAFTAR PUSTAKA}

Adam, R. 2003. Social Work and Empowerment (3rd Edition. Palgrave Macmillan: New York.

Alston, M. \& Bowles, W. 2003. Research for Social Workers. An Introduction to Methods (2nd edition). Canberra: Allen \& Unwin.

Brown, H. D. 2000. Teaching by Principles: An Interactive Approach to Language Pedagogy (2nd ed.). White Plains, NY: Longman

Burns, P.M. \& Novelli, M. 2008. Tourism and Mobilities. Local-Global Connections. London: $\mathrm{CAB}$ International.

Goeldner, C.R. \& Ritchie, B.J.R. 2009. Tourism: Principles, Practices, and Philosophies, 11th Edition, John Wiley \& Sons, Inc., Hoboken, New Jersey.

Jamal, T\& Robinson, M. 2009. The SAGE Handbook of Tourism Studies, SAGE Publications Inc., London.

Judisseno, R.K. 2017. Aktivitas dan Kompleksitas Kepariwisataan: Suatu Tinjauan tentang Kebijakan Pengembangan Kepariwisataan. Jakarta: PT. Gramedia Pustaka Utama.

Marpaung, H. \& Bahar, H. 2000. Pengantar Pariwisata. Bandung: Alfabeta, Cetakan Kesatu.

Mengkara, Ady. 2014. Pemetaan Obyek Wisata Berbasis Web dalam Rangka Promosi Pariwisata Pulau Bangka. Skripsi. Universitas Gadjah Mada. Yogyakarta.

Mondy, R. W. \& Noe, R. M. 2005. Human Resource Management. New Jersey : Pearson Education International, Upper Saddle River.

Newman, I. \& Benz, C. R. 1998. QualitatifQuantitative Research Methodology: Exploring the
Interactive Continuum. Illinois: Southern Illinois University Press. Neuman, W. L. 2007. Basic of Social Research Qualitative and Quantitative Approach (2nd edition). Boston: Perason Education Inc.

Theresia, A. dkk. 2014. Pembangunan Berbasis Masyarakat. Acuan Bagi Praktisi, akademisi, dan pemerhati pengembangan masyarakat. Bandung: Penerbit Alfabeta.

Thomas, M. and Pierson, J. (1995) Dictionary of Social Work, London, Collins Educational

Santana, K. Septiawan. 2007. Menulis Ilmiah: Metode Penelitian Kualitatif. Jakarta: Yayasan Obor Indonesia.

Simanjuntak, B.A., Tanjung, Flores, I., \& Naasution, Rosramadhana. 2017. Sejarah Pariwisata: Menuju Perkembangan Pariwisata Indonesia. Jakarta: Yayasan Pustaka Obor Indonesia.

Soetomo. 2015. Pemberdayaan Masyarakat. Mungkinkah Muncul Antitesisnya? Cetakan III. Yogyakarta: Pustaka Pelajar.

Subroto, Edi. 1992. Pengantar Metode Penelitian Linguistik Struktural. Surakarta: Sebelas Maret University Press.

Sudaryanto. 1988. Metode Linguistik (Bagian Pertama). Yogyakarta: Gadjah Mada University Press.

Suharsimi A. 2009. Manajemen Penelitian. Jakarta: Rineka Cipta.

Wardhani, R.S. \& Valerina, D. 2016. Green Tourism dalam Pengembangan Pariwisata Bangka Belitung. Prosiding Seminar Nasional Indocompac. Jakarta: Universitas Bakrie. 
UU. RI. No. 10 Tahun 2009 tentang Pariwisata.

UU.RI No. 13 tahun 2003 tentang Ketenagakerjaan 